\title{
GREEN BONDS: WORLD'S EXPERIENCES, CURRENT STATUS AND PROPOSAL FOR IMPROVING VIETNAMESE LAW
}

\author{
Dr. Luu Quoc Thai \\ Lecturer \\ Faculty of Commercial Law \\ Hochiminh city University of Law, Vietnam \\ E-mail: lqthai@hcmulaw.edu.vn
}

Received: October 14, 2021 Accepted: October 28, 2021 Online Published: November 14, 2021

DOI: 10.46281/aijssr.v9i1.1437

URL: https://doi.org/10.46281/aijssr.v9i1.1437

\begin{abstract}
Vietnam is a developing country, often adversely affected by environmental pollution and climate change. One of the main reasons leading to this situation is outdated production technologies, which is not environmentally friendly. This situation has been causing serious impacts on the economy and society of this country. According to the experience of developed countries and to fulfill national commitments on the environment, investment projects in production and business are encouraged to be implemented in an environmentally friendly manner. To do this, investors, especially businesses, need to mobilize a certain financial source to equip facilities and production technologies that cause less pollution. Among financial instruments, green bonds are an emerging factor applied by many countries around the world and Vietnam is also ready to test it. However, up to now, the issuance of green bonds in Vietnam has not been possible because of the lack of a complete legal mechanism. So, this article will analyze Vietnamese law on this issue on the basis of learning experiences from other countries to come up with a complete solution for Vietnam.
\end{abstract}

Keywords: Green bonds, Climate Changes, Vietnam, Law.

\section{INTRODUCTION}

Environmental pollution and climate change are serious global problems. In particular, developing countries like Vietnam have been experiencing great adverse impacts from these factors. According to research by international organizations and authorities, Vietnam is a country that can lose about 15 billion USD/year due to climate change, approximately 5\% of the country's GDP (UNU, 2013). Vietnam has also joined the United Nations Framework Convention on Climate Change (UNFCCC) on November 16, 1994 and is making efforts to reduce greenhouse gases.

According to the International Energy Organization (IEA), to halve global emissions by 2050, the world will need 46 trillion USD, equivalent to 1 trillion USD per year (SNRD, 2012). In that context, green bonds are seen as a new capital attraction channel and an effective solution that 
can help mobilize hundreds of billions of dollars per year for the development of a green and sustainable economy (Mai, Tap chi Tai chinh, 2019). According to a survey by the Global Green Growth Institute (GGGI), it is estimated that to fully realize the country's self-determined contributions and green growth strategy, Vietnam will need 30 billion USD in 2030 (GGGI, 2018). Therefore, green bonds are being considered as a new and effective channel to attract capital for solutions to adapt and mitigate the impacts of climate change in Vietnam (P.V, 2018).

However, until now, specific regulations on green bonds in Vietnam have not been fully issued. This makes fundraising activities for environmental protection through green bonds still facing many obstacles and difficulties and cannot be implemented in practice, although the Ministry of Finance has intended to allow this type of bond to be issued in 2021 (Dung, Bringing green bonds to the market soon in 2021, 2021).

\section{Domestic Research}

\section{LITERATURE REVIEW}

In Vietnam, the issue of green bonds has had a number of studies such as, the article: "Green bonds: Vietnam in an effort to catch up with the global green finance era" (2020) published in the Banking Journal of Vietnam by Quan Thu Trang (Trang, 2020). This article analyzes the potential development of green bonds in Vietnam - a popular green financial instrument in the world today. Based on a theoretical approach to the concept, characteristics and standards of green bonds as well as the practice of the global green bond market, The article analyzes some challenges in green bond development and recommends some solutions to promote green bond development in Vietnam.

Article: "Green bonds: Advantages and disadvantages for development in Vietnam's stock market" (2020) by the author group Minh Chau - Dang Dong - Ngoc Phat - Le Nam published in the Money Financial Market Journal. This article is based on an analysis of the interest and needs of investors in the market to assess the advantages and disadvantages of developing green bonds in the Vietnamese stock market (Minh Chau, Dang Dong, Ngoc Phat, Le Nam, 2020).

Article: "Development trend of green bond market in the world and experience for Vietnam" by Nguyen Thi Tuyet Mai published in Vietnamese Financial Review Journal. This article describes the practice of developing green bonds in some countries around the world and suggests lessons learned in policy making to develop the green bond market in Vietnam (Mai, Development trend of green bond market in the world and experience for Vietnam, 2019).

\section{International Research}

Internationally, there are some studies, such as article: "EU green bond standard: reasonable implementation can define a new asset class" of Alexander Lehmann (2021). This article discusses the European Union's green bond standard and its implementation mechanism for EU countries, aiming to perfect it as a capital asset market (Lehmann, 2021).

Article: "Financing green: reforming green bond regulation in the United States" by Echo Kaixi Wang (2018) published in the Brooklyn Journal of Corporate, Finance and Commercial Law. The article assesses the current situation of green bond issuance in the world and the situation in the United States, points out the inadequacies of the US law on green bonds and offers complete solutions (Wang, 2018).

Article: "Green bonds as a tool to combat climate change?" by Serena Fatica and Robert Panzica published in Business Strategy and the Environment Journal on March 19, 2021. In this paper, the authors investigate the relationship between the issuance of green bonds and the 
environmental performance of enterprises and aims to show the real effect of green bonds in protecting the environment and preventing climate change. Research results show that the majority of green bonds of enterprises are issued to finance projects with the aim of mitigating climate change (Serena Fatica \& Robert Panzica, 2021).

Article: "What Future for the Green Bond Market? How Can Policymakers, Companies, and Investors Unlock the Potential of the Green Bond Market?" by Pauline Dyschryver and Frederic de Mariz (2020) published in Journal of Risk and Financial Management. This paper is based on a unique methodology that combines an extensive literature review, analysis of market data, and interviews with multiple green bond market participants. The authors identify current barriers that explain the lack of scalability of the green bond market: the lack of globally harmonized standards; the risk of "green washing"; higher cost awareness for issuers; lack of supply of green bonds for investors; and the early stages of the market. This paper makes some recommendations to overcome these obstacles and exploit the full potential of green bonds to finance sustainability goals (Mariz, Pauline Dyschryver \& Frederic de, 2020).

In general, the researches on green bonds that have been published mainly focus on economic and environmental aspects. The author has not found any works that go into the analysis of the legal aspects of this issue in Vietnam.

\section{METHODOLOGY}

This article is based on the "Sustainable Development" theory outlined in the 1972 Stockholm Declaration (at the Conference on Human Environment held in the Swedish capital in 1972): "It is development that meets the needs of the present without compromising the satisfaction of the needs of future generations". The article is also based on the United Nations Framework Convention on Climate Change (which came into force on March 21, 1994), with the main content being: "the stabilization of greenhouse gas concentrations in the atmosphere at dangerous anthropogenic interference with the climate system could be prevented. That level must be reached within a time frame sufficient to allow ecosystems to adapt naturally to climate change, to ensure that food production is not threatened, and to enable growth sustainable economic development". Based on this, the author uses the desk-based research method through the processing of indirectly collected information. Methods of analysis, evaluation, comparison and synthesis of information will be used in the discussion to find out the research results.

\section{DISCUSSION AND RESULTS \\ Theoretical and Practical Basis of Green Bonds \\ A. Theoretical basis of green bonds}

Green bonds were born in 2008 by the World Bank for the purpose of financing environmental projects (World Bank, 2018). Although investors were not interested at first, when environmental problems became more and more serious, green bonds became one of the new capital raising tools that were widely developed in many countries around the world with many issuers such as the European Investment Bank (EIB), Asian Development Bank (ADB), Development Bank in Japan, Germany and in some local governments in European countries, America, Europe (Minh Chau, Dang Dong, Ngoc Phat, Le Nam, 2020),...

In fact, in the world today, there are two international regulatory systems that bond issuers can refer to when issuing green securities. The first is the Green Bond Principles (GBP), published in 2014 by the International Capital Market Association (ICMA) and several major investment

banks. The second is the Climate Bond Standard (CBS), which establishes recommendations of 
industry-specific standards that climate bonds need to meet before they can be certified. Both guidelines are voluntary and there is no supervisory mechanism to enforce them (ICMA, 2021).

According to ICMA's 2014 Green Bond Principles (GBP), a green bond is any type of bond in which the proceeds from the bond issue are used for financing or refinancing part or all of projects related to the environment, also known as green projects such as clean energy, clean water projects... Different countries, organizations and regions will have their own ways and regulations on the issuance of these bonds, but all are based on an international standard "GBP". In particular, green bonds need to comply with four principles specified in GBP: using proceeds, evaluating and selecting projects, managing proceeds and reporting on capital use.

In the research paper: "Developing the green bond market in China: Reducing costs and increasing the capacity of green investments while promoting greater transparency and stability in financial markets" by Kidney \& Oliver (2014) posted on the website of the International Sustainable Development Organization, green bonds, just like regular bonds but issued with the purpose of supporting green investments - investments that aim to reduce environmental impact such as reducing climate change or increasing efficiency energy (Oliver, 2014).

It can be said that green bonds are distinguished from ordinary bonds through commitments to use mobilized capital to finance or refinance green projects or businesses. Green bonds can be issued by public entities such as the government, local authorities or the private sector such as banks and businesses to raise capital for projects associated with the environment.

According to ICMA's 2018 edition of the Code of Conduct for Green Bonds Issue and Use (GBP), the qualifying Green Project categories are listed below in no particular order, including, but are not limited to:

- $\quad$ renewable energy (including production, transmission, appliances and products);

- energy efficiency (such as in new and refurbished buildings, energy storage, district heating, smart grids, appliances and products);

- pollution prevention and control (including reduction of air emissions, greenhouse gas control, soil remediation, waste prevention, waste reduction, waste recycling and energy/emission-efficient waste to energy);

- environmentally sustainable management of living natural resources and land use (including environmentally sustainable agriculture; environmentally sustainable animal husbandry; climate smart farm inputs such as biological crop protection or drip-irrigation; environmentally sustainable fishery and aquaculture; environmentally-sustainable forestry, including afforestation or reforestation, and preservation or restoration of natural landscapes);

- terrestrial and aquatic biodiversity conservation (including the protection of coastal, marine and watershed environments);

- clean transportation (such as electric, hybrid, public, rail, non-motorised, multi-modal transportation, infrastructure for clean energy vehicles and reduction of harmful emissions);

- sustainable water and wastewater management (including sustainable infrastructure for clean and/or drinking water, wastewater treatment, sustainable urban drainage systems and river training and other forms of flooding mitigation);

- climate change adaptation (including information support systems, such as climate observation and early warning systems);

- eco-efficient and/or circular economy adapted products, production technologies and processes (such as development and introduction of environmentally sustainable products, 
with an eco-label or environmental certification, resource-efficient packaging and distribution);

- green buildings which meet regional, national or internationally recognised standards or certifications.

Thus, green bonds are also a debt instrument to raise capital like all bonds, but green bonds have specific characteristics associated with the purpose of using the mobilized capital. It is the proceeds from the issuance of green bonds that must be used to finance or refinance green projects. In order to manage the money collected from green bonds and use it for the right purposes, a reputable third party must perform the monitoring and management to ensure transparency and accuracy. If green projects do not bring revenue to the issuer, other revenue sources of the issuer can be used to ensure debt repayment, such as local government budget revenues, state budget revenue.

Theoretically, the use of green bonds benefits bond issuers, investors and society. Issuing green bonds on the market will help attract a variety of investors, especially those who are interested in environmental factors. In terms of society, green bonds will contribute to raising the awareness of investors about environmental issues, and at the same time, create conditions to attract large capital from the society to realize green growth, economic sustainable development.

\section{B. Practical application of green bonds in some countries around the world Green bonds in Singapore}

In 2017, The Monetary Authority of Singapore (MAS) launched the Green Bond Program. This is a remarkable move by policy makers in promoting the development of green finance in the financial system. MAS offers a 3-year support program from June 1, 2017 to May 31, 2020 for issuers (enterprises and credit institutions) that must meet the following conditions (GBS Vietnam, 2021):

- Issued in Singapore Dong (SGD) and listed on the Singapore Stock Exchange. The issuer does not have to be a Singapore company;

- Issuing value is at least 200 million SGD and has a term of at least 3 years, which cannot be recovered in those 3 years;

- Enterprises must prepare and submit an independent assessment report or credit rating report according to internationally recognized green bond issuance standards. (The International Capital Market Association's Green Bond Principles - GBP), climate bond standards or ASEAN Green Bond Standards (Asean Green Bond Standards).

In addition, the Singapore Government's move to issue green bonds for $\mathrm{S} \$ 19$ billion worth of infrastructure projects has positioned the country as a trusted hub for green finance. These green bonds are significant as the total number of green bonds issued by ASEAN from 2016 to 2019 is only approximately US $\$ 8.1$ billion ( $\mathrm{S} \$ 10.8$ billion), of which $55 \%$ contributed by Singapore (Lin, 2021).

\section{Green bonds in China}

China is the world's leading greenhouse gas producer (Phong, 2021). In order to have financial resources to deal with environmental pollution and climate change, China has officially mobilized capital with green bonds since 2015. Agricultural Bank of China issued nearly 1 billion USD of green bonds in the London market to raise capital for environmentally friendly projects in October 2015 (Chau, 2018). China's domestic green bond market was established in December 2015 with the first amount of green bonds issued on the interbank market, in order to help credit institutions, 
raise more capital to finance their investments green project, and at the same time establish a market to create a basis for the development of the green bond market in the following years. China's green bond issuance value increased to 36.2 billion USD, accounting for one-third of the global green bond issuance value, making China the leading country in this market. In the first months of 2021, China took the lead in green bond issuance (Huang, 2021).

To achieve the above results, China has built a specific legal corridor. On December 22, 2015, the People's Bank of China (PBoC) issued the Directive on Green Financial Bonds, which stipulates the following contents: (1) the concept of green bond, (2) the list of industries that green bonds finance, (3) entities that are allowed to issue green bonds, (4) procedures to apply for green bonds, (5) issuance as well as principles in the process of using and managing revenue from green bond issuance, (6) regulations to encourage relevant agencies and sectors to take measures to support the development of green bonds. In addition, the PBoC also issued a List of projects financed by green bonds - setting standards for projects, industries and sectors to consider financing with funds from green bond issuance. These standards are developed based on reference to international standards combined with China's environmental policy. This is the first specific guide on green bonds in China. After that, a series of directional documents and guidelines for the development of green bonds were issued. In mid-November 2016, China's National Development and Reconstruction Commission (NDRC) issued guidelines for green bond issuance mainly aimed at the state-owned enterprise sector, specifying which projects are considered as green green projects, and outlines the requirements for the issuance of green bonds and related policies. Around the end of March 2016, the Shanghai Securities Center and the Shenzhen Securities Center issued the Notice of Green Bond Pilot Program, facilitating the listing of green bonds on the external financial market next to the interbank bond market. By the end of August 2016, China continued to issue the Guidelines for building a green financial system, which concretize guidelines to promote the role of the stock market in green investment and unify domestic green bond standards (Hong, 2017).

In addition, China has also issued preferential policies to encourage the development of the green bond market. In particular, the PBoC has approved for financial institutions to use green bonds as collateral to enjoy low-interest loans from the central bank. This regulation has created a driving force for banks to issue green bonds in the process of raising capital. This is one of the reasons why commercial banks account for the largest share, up to $82 \%$, in the issuance of green bonds in China. Guidelines issued by the NDRC have provided incentives for businesses to issue green bonds, such as simplifying the issuance and approval process for companies. This is specifically through allowing companies to be issued individually and collectively for certain types of projects and under certain circumstances, adjusting some conditions for issuing green bonds for businesses, for example allowing the bond issue value to account for $80 \%$ of the total investment of the project. At the same time, China allows issuers to use green bonds to improve capital structure, i.e., the issuer is approved to use less than $50 \%$ of the proceeds from the bond to pay off bank liabilities and invest in working capital (Anh, 2020).

Being allowed to trade on international stock markets as well as domestic financial markets has created a large market for Chinese green bonds to develop. In 2016, 27\% of China's green bonds were issued overseas with 3 currencies: USD, RMB and EUR. Among the issued green bonds, $17 \%$ of green bonds meet international green bond standards and are traded in the London and Singapore markets. However, it is the domestic green bond market that shows the strong development of China's green bonds when the domestic issuance rate is up to $72 \%$ of the total amount of green bonds. Of which, 74\% of green bonds are issued on the interbank market and 
17\% traded on the Shanghai stock market (Chau, 2018). Thus, the development of the domestic green bond market, mainly in the interbank market, has facilitated the trading of green bonds, promoting the development of green bonds.

In short, careful legal and technical preparation as well as systematic and synchronous steps have contributed to helping China's green bonds achieve positive results and in the coming years will still be one of the important capital attraction channels to help China achieve its plan of greening the economy (Climate Bonds, 2021).

\section{Green Bonds in Europe}

Europe is a region with a very large amount of green bonds has been issued. Previously, the issuance of green bonds in Europe was based on the ICMA' GBP on a voluntary basis. Let's do the statistics of bonds issued in the world to compare. In 2014, green bonds were issued worldwide worth $\$ 36.8$ billion ( $€ 31.1$ billion). Six years later, in 2020 , the market reaches 290.1 billion USD (245 billion euros). According to the Climate Bonds Initiative, an international organization that mobilizes green capital, 2021 will end with more than $\$ 450$ billion ( $€ 380$ billion) raised for climate projects. For 2023, forecast is 1 trillion USD. Although the US is the leading country in issuing green bonds, it is the EU countries that are ahead: Germany, France, the Netherlands, Sweden and Spain - are among the top 10 green bond issuers. In 2020, these five countries together issued $\$ 120$ billion in green bonds, accounting for more than $40 \%$ of the total global bond. Meanwhile, the US and China issued 52.1 billion USD and 22.4 billion USD respectively. Italy, Finland, Portugal, Denmark, Hungary, Austria, Luxembourg, Belgium, Ireland, Greece and Lithuania have raised money for their national projects with green bonds, although to a much lesser extent than the top 5 EU countries. In 2021 Latvia, Poland and Slovakia begin to enter this market. Outside the EU, Norway, the United Kingdom, Switzerland, Russia and Iceland are also having certain calculations. It is predicted that in the next 5 years, the EC can issue up to 250 billion euros of green bonds to help member states implement environmentally friendly initiatives (Dung, EU "dominates" the green bond market, 2021).

For an honest, sustainable green bond market, the European Commission has proposed a green bond standard for Europe (EUGBS). On 6 July 2021, the European Commission published a legislative proposal on European green bonds (the EuGB Regulation). The EuGB Regulation will lay the foundation for a common framework of rules regarding the use of the "European Green Bond" (EuGB) designation for bonds that pursue environmentally sustainable objectives as defined by the Taxonomy Regulation. It also sets up a system for registering and supervising companies that act as external reviewers for green bonds aligned with the EuGB framework (NortonRoseFulbright, 2021). This is an important premise so that in October 2021, the EU issued a record high green bond, serving its needs and taking its first step to potentially become the biggest issuer of environmentally-friendly debt with a record-sized deal (Bahceli, 2021).

\section{Green Bonds in The United States}

The United States (US) is the second largest producer of greenhouse gases in the world, after China (Chiang, 2017). Therefore, the direction of green industry is always interested by the government and businesses in the US. Apple, Inc. had the largest green bond issuance because with the goal of financing green buildings, renewable energy projects and "robot technology to popularize used iPhones and preserve high quality components" (Eck, 2017). Besides, other large banks and corporations, such as Bank of America, Morgan Stanley and some energy companies have started to issue green bonds to finance initiatives for green production, such as: Build wind farms to 
generate electricity, and develop residential solar power systems. This has made the amount of green bonds in the US always top in the world. Comparison with other countries shows that, in the five years leading up to 2021, US issuers accounted for the largest share of issuance by volume (17\% or $\$ 37.6$ billion) and number of transactions (495). Germany came in second with $13 \%$, or $\$ 28.5$ billion, and 102 deals, while France and China came in third and fourth, with similar volumes ( $\$ 22.8$ billion and 22.0 billion USD, each deal accounts for $10 \%$ of the issuance) but the number of transactions varies (20 and 92 respectively). Singapore comes in at 13th place, between Norway and the UK (Dung, Global green bond market to reach record $\$ 1$ trillion by the end of 2022, 2021).

Just like the European green bond market, the US green bond market governance system and practices remain entirely voluntary and the regulatory systems are largely self-regulating through GBP guidelines. The US green bond market is mainly operated through sustainable investment funds. This leads to debates about the standard of green bonds, green projects and the transparency required in the issuance and use of green bonds. Therefore, in order for the green bond market to be stable and correct, experts have recommended that the US government consider issuing its own regulation on green bonds like China and EU had done, so that investors who are considering investing in green bonds will have more confidence in the reliability and safety of their investments.

A new information related to international standards on green bonds worth noting is that, in 2021, ICMA also issued the 2021 Version of GBP. This edition of GBP benefits from the feedback of the 2020 consultations by the Members and Observers of the Principles, the Advisory Council, as well as from the input of working groups led by the Executive Committee coordinated with the support of the Secretariat. This is an important basis for green bonds to develop sustainably in the world.

\section{Current Status of Vietnamese Law on Green Bonds}

In order to fulfill international environmental commitments, over the past time, Vietnam has issued many oriented mechanisms and policies on developing the green bond market such as:

- National strategy on green growth according to Decision No. 1393/QD-TTg dated September 25, 2012 of the Prime Minister;

- National action plan on green growth (Decision No. 403/QD-TTg dated September 20, 2014 of the Prime Minister);

- Decision No. 1191/QD-TTg dated August 14, 2017 of the Prime Minister approving the Roadmap for the development of the bond market for the period 2017-2020, with a vision to 2030. This is considered an important legal basis for the development of the green bond market in Vietnam.

In addition, the Communist Party of Vietnam, the Government and the Ministry of Finance have issued legal documents to create a favorable legal corridor for green development in Vietnam. The first is Resolution No. 24-NQ/TW dated June 3, 2013 of the XI Central Executive Committee on proactively responding to climate change, strengthening financial management and protecting the environment by 2020 towards a green and environmentally friendly economy, by 2050 achieving environmental targets equivalent to those of industrialized countries in the region. On this basis, the Prime Minister issued the following documents:

- Decision No. 403/QD-TTG approving the National Green Growth Action Plan for the period $2014-2020$;

- $\quad$ Action plan to implement the Paris Agreement on climate change (Decision No. 2053/QD-TTG dated October 28, 2016). 
After that, the Ministry of Finance issued Decision No. 2183/QD-BTC dated October 20, 2015 promulgating the Action Plan of the Finance sector to implement the national strategy on green growth until 2020, including the following objectives and specific duties are as follows: Completing financial policies related to promoting the implementation of the Green Growth Strategy; Develop and complete a financial policy framework to develop green capital markets and green financial products; Review and complete the credit policy framework and support of the State.

Recently, Decree 95/2018/ND-CP dated June 30, 2018 stipulates the issuance, registration, custody, listing and trading of government debt instruments on the stock market and Decree 153/2020/ND-CP dated December 31, 2020 stipulating the private offering and trading of corporate bonds in the domestic market and the offering of corporate bonds to the international market has officially regulated on green bonds. The Law on Environmental Protection 2020 (effective from January 1, 2022) is the first Law on Environmental Protection of Vietnam that officially regulates green bonds as a tool to support environmental protection activities.

Article 150 of the Law on Environmental Protection 2020 provides for green bonds as follows:

"1. Green bonds are bonds issued by the Government, local authorities and enterprises in accordance with the law on bonds to raise capital for environmental protection activities and investment projects that bring environmental benefits.

2. Financial source from issuing green bonds must be accounted and monitored according to the provisions of the law on bonds and used for investment projects in the field of environmental protection, investment projects that bring about environmental benefits, including:

a) Renovating and upgrading environmental protection works;

b) Changing technology towards applying the best available technology;

c) Applying circular economy, green economy, low carbon emission;

d) Prevent and reduce environmental pollution;

d) Improve and restore the environment after an environmental incident;

e) Effectively use natural resources, land resources, save energy, develop renewable energy sources;

g) Building multi-purpose, environment-friendly infrastructure;

h) Efficient management of water resources and wastewater treatment;

i) Adapting to climate change, investing in development of natural capital;

k) Other investment projects as prescribed.

3. The issuer of green bonds must provide information about the environmental impact assessment, the environmental permit of the investment project, and the use of capital raised from the issuance of green votes to investors.

4. Issuers and investors buying green bonds are entitled to incentives in accordance with this Law and other relevant laws.

5. The Government shall detail this Article."

In fact, as mentioned above, before the Law on Environmental Protection 2020, the concept of green bonds was officially explained in the legal document on securities. Accordingly, "Green corporate bonds" are corporate bonds issued to invest in projects in the field of environmental protection, projects that bring environmental benefits in accordance with the provisions of the law on environmental protection" (Clause 1, Article 21 of Decree 98/2015/ND-CP, Clause 2, Article 4 of Decree 153/2020/ND-CP).

Regarding the issue, according to Clause 3, Article 21 of Decree 95/2018/ND-CP, the 
terms, conditions, and arrangements for the issue, registration, depository, listing and trading of Green Government bonds shall be implemented accordingly to the provisions of Article 14, Article 15, Article 16, Article 17, Article 18, and Article 19 of this Decree, i.e., like ordinary bonds. However, important issues have been assigned to the Ministry of Finance, the Ministry of Planning and Investment, and the Ministry of Natural Resources and Environment to develop a green bond issuance scheme to report to the Prime Minister for approval before implementation currently not available yet. Specifically include the following issues:

a) Purpose of issuing bonds;

b) Volume of bonds issued;

c) Terms and conditions of the bond;

d) Green bond buyers;

d) Method of issuing bonds;

e) Registration, custody, listing and trading;

g) List of projects using capital from bond issuance.

In addition, according to Clause 3, Article 5 of Decree 153/2020/ND-CP, capital from bond issuance must be separately accounted, managed, monitored and disbursed for projects in the field of environmental protection, projects with environmental benefits according to the approved release plan.

Thus, Vietnam only has the most basic and prerequisite regulations for the issuance of green bonds, but specific regulations for implementation have not been issued yet. Although on August 7, 2018, the State Bank of Vietnam issued Decision 1604/QD-NHNN approving the green bank development project, aims to gradually increase the proportion of credit capital for green sectors and fields that need priority support in the list of green projects promulgated by the State Bank, but this project also sets only "striving" goals, not mandatory targets. Therefore, the issue of green credit in general and green bonds in particular in Vietnam still exists only on paper but has not been implemented in practice. In fact, no local government has yet issued a report on the implementation and evaluation of the effectiveness of projects using capital from green bonds (Tan, 2019).

In addition to the problems mentioned above, important issues need to be urgently clarified, such as: "green standards"; management and control of the use of green bonds for the right purposes. In fact, in the world, there has been a situation of taking advantage of green bond and green credit policies to serve other economic purposes. That's called "green washing" behavior. (Greenwashing). "Green washing" is understood as when a company spends time and money advertising and marketing that its goods or services are environmentally friendly when in fact it is not. In other words, green washing is the act of making false or misleading statements about the environmental benefits of a product, service, or technology, (CFI, 2021) v.v. They issue green bonds by advertising green initiatives, but instead operate in a way that harms the environment. It can also happen when issuers make misleading statements about how beneficial the project is to environmental causes or when they fail to establish supporting evidence for the green claims they make.

\section{CONCLUSION AND RECOMENDATION}

Green bonds are being considered as a new and effective channel to attract capital for solutions to adapt and mitigate the impacts of climate change in many countries around the world. For the State, the issuance of green bonds can be a solution to mobilize capital for urgent national projects in the field of environment, combating climate change... For businesses, green bonds will be a 
good tool for them to implement renewable energy projects such as wind power, solar energy or invest in waste treatment systems, minimizing adverse impacts on the environment.

However, as mentioned above, legally, Vietnam still lacks many specific regulations on the issuance of green bonds, such as: criteria for green project selection, environmental performance assessment... that green projects bring to society. Because of these inadequacies, the issue of green bond issuance in Vietnam is still at the stage of research and survey. Of course, Vietnam can also voluntarily apply ICMA's GBP principles to issue green bonds, but it may encounter unwanted negative effects.

Therefore, in order to quickly and effectively take advantage of this financial instrument, the Vietnamese Government should soon have the following specific regulations:

- List of projects eligible for funding incentives from green bonds;

- Specific criteria to evaluate the "green" level that a project brings;

- Specific incentives for issuers and users of green bonds;

- Mechanism to control the release use of capital from green bonds;

- Handling of violations related to the improper use of preferential policies on green bonds, especially the issue of "green washing".

\section{REFERENCES}

Anh, T. T. (2020). Experience in building a green financial system in China. Retrieved from Tap chi Ngan Hang: http://tapchinganhang.gov.vn/kinh-nghiem-xay-dung-he-thong-tai-chinhxanh-tai-trung-quoc.htm

Bahceli, Y. (2021). EU launches first green bond with record size and demand. Retrieved from Reuters: https://www.reuters.com/business/sustainable-business/eu-starts-sale-debutgreen-bond-ifr-2021-10-12/

CFI, F. I. (2021). What is Greenwashing? Retrieved from https://corporatefinanceinstitute.com/resources/knowledge/other/greenwashing/

Chau, N. T. ( 2018). China's experience in developing green bonds for Vietnam. Retrieved from https://gec.edu.vn/tong-hop/kinh-nghiem-phat-trien-trai-phieu-xanh-cua-trung-quoc-choviet-nam.html

Chiang, J. (2017). Growing the U.S. Green bond market: Volume 1: The barriers and challenged 11. Retrieved from http://www.treasurer.ca.gov/green bonds/publications/reports/green_bond_market_01.pdf

ClimateBonds. (2021). China totalled USD44bn in lablled green bonds during 2020: Second largest country for green issuance. Retrieved from ClimateBonds: https://www.climatebonds.net/2021/09/china-totalled-usd44bn-labelled-green-bondsduring-2020-second-largest-country-green)

Dung, V. (2021). Bringing green bonds to the market soon in 2021. Retrieved from Tap chi Tai chinh: https://tapchitaichinh.vn/kinh-te-vi-mo/som-dua-trai-phieu-xanh-vao-thi-truongtrong-nam-2021-333149.html 
Dung, V. (2021). EU "dominates" the green bond market. Retrieved from https://congthuong.vn/eu-thong-tri-thi-truong-trai-phieu-xanh-164478.html

Dung, V. (2021). Global green bond market to reach record \$1 trillion by the end of 2022. Retrieved from congthuong.vn: https://congthuong.vn/thi-truong-trai-phieu-xanh-toancau-tien-den-moc-ky-luc-1-nghin-ty-usd-vao-cuoi-nam-2022-166641.html

Eck, V. (2017). How Investors Can Evaluate the Impact of a Green Bond. Retrieved from MKT. REALIST: http://marketrealist.com/2017/05/u-s-corporate-green-bonds-faring

GBSVietnam. (2021). Experience in building a green financial system in Singapore. Retrieved from https://congtrinhxanhvn.com/kinh-nghiem-xay-dung-he-thong-tai-chinh-xanh-taisingapore.html

GGGI. (2018). Potential of green bonds in Vietnam. Retrieved from Global Green Growth Institue: https://www.greenfinanceplatform.org/sites/default/files/downloads/resource/GGGI-VietNam-Green-Bond-Market-Survey-Final-200925.pdf

Hong, N. T. (2017). China's green financial system development strategy. Retrieved from ncif.gov.vn: http://ncif.gov.vn/Pages/NewsDetail.aspx?newid=19481

Huang, A. (2021). China's $\$ 113$ Billion Green Bonds Caught in Jumble of Rules. Retrieved from reuters.com: https://www.reuters.com/article/us-china-bond-green-idUSKBN2BO4FP

ICMA. (2021). What are the Green Bond Principles. Retrieved from ICMA: https://www.icmagroup.org/assets/documents/Sustainable-finance/2021-updates/GreenBond-Principles-June-2021-140621.pdf

Lehmann, A. (2021). The EU green bond standard: sensible implementation could define a new asset class. Retrieved from Bruegel: https://www.bruegel.org/2021/07/the-eu-green-bondstandard-sensible-implementation-could-define-a-new-asset-class/

Lin, F. E. (2021). Commentary: Here's how green bonds will take Singapore's reputation as a finance hub to the next level. Retrieved from channelnewsasia: https://www.channelnewsasia.com/commentary/budget-2021-green-bond-infrastructurefinance-invest-sustainable-1883071

Mai, N. T. ( 2019). Tap chi Tai chinh. Retrieved from Development trend of green bond market in the world and experience for Vietnam : https://tapchitaichinh.vn/kinh-te-vi-mo/xu-huongphat-trien-thi-truong-trai-phieu-xanh-tren-the-gioi-va-kinh-nghiem-cho-viet-nam302121.html

Mai, N. T. (2019). Development trend of green bond market in the world and experience for Vietnam. Retrieved from Tap chi Tai chinh. 
Mai, N. T. (2019). Development trend of green bond market in the world and experience for Vietnam. Retrieved from Tap chi Tai chinh: https://tapchitaichinh.vn/kinh-te-vi-mo/xuhuong-phat-trien-thi-truong-trai-phieu-xanh-tren-the-gioi-va-kinh-nghiem-cho-viet-nam302121.html

Mariz, Pauline Dyschryver and Frederic de. (2020). What Future for the Green Bond Market? How Can Policymakers, Companies, and Investors Unlock the Potential of the Green Bond Market? Retrieved from Journal of Risk and Financial Management: https://www.mdpi.com/1911-8074

Minh Chau, Dang Dong, Ngoc Phat, Le Nam. (2020). Green bonds: Advantages and disadvantages for development in Vietnam's stock market. Retrieved from Tap chi Thi Truong - Tien te: https://thitruongtaichinhtiente.vn/trai-phieu-xanh-thuan-loi-va-khokhan-de-phat-trien-o-thi-truong-chung-kho

NortonRoseFulbright. (2021). European Commission publishes legislative proposal on European green bonds. Retrieved from NortonRoseFulbright: https://www.nortonrosefulbright.com/en/knowledge/publications/6d61dde7/europeancommission-publishes-legislative-proposal-on-european-green-bonds

Oliver, S. K. (2014). Growing a Green Bonds Market in China: Reducing costs and increasing capacity for green investment while promoting greater transparency and stability in financial markets. Retrieved from ISSD: https://www.iisd.org/system/files/publications

P.V. (2018). Green government bonds - new capital attraction channel. Retrieved from Tap chi Tai chinh: https://tapchitaichinh.vn/kinh-te-vi-mo/trai-phieu-chinh-phu-xanh-kenh-hutvon-moi-141373.html

Phong, T. (2021). China is the world's 'champion' of greenhouse gas emissions. Retrieved from thanhnien.vn: https://thanhnien.vn/trung-quoc-xa-khi-thai-nha-kinh-vo-dich-the-gioipost $1064908 . h t m l$

Serena Fatica \& Robert Panzica . (2021). Green bonds as a tool against climate change? Retrieved from https://doi.org/10.1002/bse.2771

SNRD, A. (2012). Strategic mainstreaming of ecosystem-based adaptation in Vietnam. Retrieved from SNRD ASIA/PACIFIC: https://snrd-asia.org/strategic-mainstreaming-of-ecosystembased-adaptation-in-vietnam-eba/

Tan, D. T. (2019). Potential for development of green bonds in Vietnam. Retrieved from Tap chi Cong thuong: https://tapchicongthuong.vn/bai-viet/tiem-nang-phat-trien-trai-phieu-xanho-viet-nam-67206.htm

Trang, Q. T. (2020). Vietnam in an effort to keep pace with the global green era. Retrieved from Tap chi Ngan Hang: http://tapchinganhang.gov.vn/trai-phieu-xanh-viet-nam-trong-no-lucbat-nhip-voi-ky-nguyen-tai-chinh-xanh-toan-cau.htm 
UNU, U. N.-W. (2013). The cost of climate change in Vietnam. Retrieved from United Nation University: https://www.wider.unu.edu/publication/cost-climate-change-vietnam

Wang, E. K. (2018). Financing green: reforming green bond regulation in the United States. Brooklyn Journal of CorporateFinance and Commercial Law, 12(2), 468-491.

WorldBank. (2018). World Bank Marks 10-Year Green Bond Anniversary with Landmark Issuance US\$1.3 Billion Issuances Bring World Bank Green Bond Program to US\$12.6 Billion. Retrieved from World Bank: https:/www.worldbank.org/en/news/pressrelease/2018/11/13/world-bank-marks-10-year-

\section{Copyrights}

Copyright for this article is retained by the author(s), with first publication rights granted to the journal. This is an open-access article distributed under the terms and conditions of the Creative Commons Attribution license (https://creativecommons.org/licenses/by/4.0) 